\title{
Minireview Biomarkers of angiogenesis and their role in the development of VEGF inhibitors
}

\author{
N Murukesh', C Dive ${ }^{2}$ and GC Jayson*,I \\ 'Department of Medical Oncology, Manchester Academic Health Science Centre, The Christie NHS Foundation Trust, Cancer Research UK and \\ University of Manchester, Wilmslow Road, Withington, Manchester M20 4BX, UK: ${ }^{2}$ Cancer Research UK and Clinical and Experimental Pharmacology \\ Group, Manchester Cancer Research Centre, Paterson Institute of Cancer Research, Withington, Manchester M20 4BX, UK
}

Vascular endothelial growth factor (VEGF) has been confirmed as an important therapeutic target in randomised clinical trials in multiple disease settings. However, the extent to which individual patients benefit from VEGF inhibitors is unclear. If we are to optimise the use of these drugs or develop combination regimens that build on this efficacy, it is critical to identify those patients who are likely to benefit, particularly as these agents can be toxic and are expensive. To this end, biomarkers have been evaluated in tissue, in circulation and by imaging. Consistent drug-induced increases in plasma VEGF-A and blood pressure, as well as reductions in soluble VEGF-R2 and dynamic contrast-enhanced MRI parameters have been reported. In some clinical trials, biomarker changes were statistically significant and associated with clinical end points, but there is considerable heterogeneity between studies that are to some extent attributable to methodological issues. On the basis of observations with these biomarkers, it is now appropriate to conduct detailed prospective studies to define a suite of predictive, pharmacodynamic and surrogate response biomarkers that identify those patients most likely to benefit from and monitor their response to this novel class of drugs.

British Journal of Cancer (2010) 1 02, 8- 18. doi:I0.1038/sj.bjc.6605483 www.bjcancer.com

Published online 15 December 2009

(c) 2010 Cancer Research UK

Keywords: VEGF; angiogenesis; biomarkers

Angiogenesis, the process of new blood vessel formation, is critical for the growth and metastasis of tumours. Early in tumourigenesis, an 'angiogenic switch' is activated by hypoxia, activated oncogenes and/or metabolic stress. The previously closely maintained physiological balance that keeps adult vasculature in a relatively quiescent state is then tipped in favour of angiogenesis through the expression of pro-angiogenic growth factors, such as vascular endothelial growth factor (VEGF) (Hanahan and Folkman, 1996). Vascular endothelial growth factor has been confirmed in multiple clinical trials as an important target for solid tumour treatment, but it is not clear who benefits from this class of drugs; this is an issue of increasing importance, bearing in mind the toxicity and expense of VEGF inhibitors in addition to the need to generate combination regimens that include VEGF inhibitors.

Although several biomarkers associated with angiogenesis measured before treatment have shown to provide prognostic value, and a few biomarkers are pharmacodynamic, there is minimal information on biomarkers that are true surrogates for clinical response to VEGF inhibitors. As VEGF-targeted therapies progress through clinical development pipelines, it may take several years to determine their clinical efficacy and overall response data. Thus, there is a pressing need for predictive and pharmacodynamic biomarkers and for those that are true surrogates of clinical response.

*Correspondence: Professor GC Jayson;

E-mail: gordon.jayson@christie.nhs.uk

Received 23 June 2009; revised 5 November 2009; accepted 18 November 2009; published online 15 December 2009

\section{VASCULAR ENDOTHELIAL GROWTH FACTOR}

Vascular endothelial growth factor is a homodimeric glycoprotein with a molecular weight of $45 \mathrm{kDa}$. The VEGF family includes VEGF-A (usually referred to as VEGF), VEGF-B, VEGF-C, VEGF-D and a structurally related molecule, placental growth factor (PIGF). Through alternative splicing of VEGF mRNA, 12 isoforms of VEGF have been identified (Nowak et al, 2008), most of which can activate the signal transducing receptors. However, through alternative splicing of exon 8, anti-angiogenic variants, designated as VEGF$\mathrm{A}_{\mathrm{xxxb}}$, can be formed, where $\mathrm{xxx}$ denotes the number of amino acids in the mature protein. Although present in the malignant colonic epithelium, the inhibitory effect of VEGF- $A_{165 b}$ is overcome by an excess of VEGF- $A_{165}$, a relationship that contributes to the relative efficacy in vivo of anti-VEGF antibodies that bind both isoforms (Bates et al, 2002; Varey et al, 2008). The clinical significance of the ratio of activating and inactivating isoforms of VEGF to the activity of VEGF inhibitors remains unclear.

Three high-affinity VEGF tyrosine kinase receptors have been identified: VEGF receptor (VEGFR)-1 (flt-1), VEGFR-2 (flt-1/KDR) and VEGFR-3 (flt-4). The binding of VEGF to these receptors initiates a cascade of signalling pathways that mediate endothelial cell (EC) migration, proliferation, survival and permeability. Additional co-receptors include neuropilins that have traditionally been implicated in cell guidance (Kawasaki et al, 1999) and increased binding of VEGF to its signalling receptor (Soker et al, 1998). However, recent data have suggested that NRP-1 may regulate EC function independently of VEGFR-2 (Murga et al, 2005), and that $\mathrm{VEGF}_{121}$ can directly interact with NRP-1 without forming an NRP-1 - VEGFR-2 complex (Pan et al, 2007). 
Table I VEGF-targeted therapies

\begin{tabular}{ll}
\hline Mechanism of action & Examples of drugs \\
\hline Anti-VEGF monoclonal antibody & Bevacizumab \\
Small molecule receptor tyrosine kinase inhibitor (TKi) & Sunitinib \\
VEGF-Trap (soluble VEGF receptor) & Aflibercept \\
\hline
\end{tabular}

Abbreviation: VEGF = vascular endothelial growth factor.

Vascular endothelial growth factor-A interacts with both VEGFR-1 and VEGFR-2 to mediate angiogenesis, whereas VEGF$B$ and PlGF have high affinity for only VEGFR-1. Vascular endothelial growth factor-C and VEGF-D bind both VEGFR-2 and VEGFR-3 (Joukov et al, 1996; Achen et al, 1998) to regulate angiogenesis and have been implicated in lymphangiogenesis (Shibuya and Claesson-Welsh, 2006). Vascular endothelial growth factor receptor-2 is the principal receptor that promotes the pro-angiogenic action of VEGF-A and has been the principal target of anti-angiogenic therapies, although additional studies have underlined the importance of signalling through VEGFR-1 (Carmeliet et al, 2001).

Various strategies for inhibiting VEGF have been investigated over the last decade. These include neutralising antibodies to VEGF (Hurwitz et al, 2004), low-molecular-weight VEGFR tyrosine kinase inhibitors (TKis) (Motzer et al, 2006; Llovet et al, 2008) and soluble VEGFR constructs (VEGF-Trap) (Riely and Miller, 2007) (Table 1).

Angiogenesis and VEGF have been confirmed as targets of anticancer therapeutics in multiple disease settings. Randomised clinical trials in the first- and second-line treatment of metastatic colorectal cancer (Hurwitz et al, 2004; Giantonio et al, 2007), breast cancer (Miller et al, 2007), non-small-cell lung cancer (Sandler et al, 2006), renal cancer (Motzer et al, 2007) and hepatocellular carcinoma (Llovet et al, 2008) have demonstrated an improvement in response, progression-free survival (PFS) and/or overall survival (OS) when conventional therapy was supplemented by VEGF inhibitors.

The demonstration of a survival advantage conferred by VEGF inhibitors is of great importance. However, the initial promise of anti-angiogenic agents, namely the reduced prevalence of drug resistance and durable stabilisation of disease, has not been realised. Vascular endothelial growth factor inhibitors also have a range of host toxicities. They are expensive and optimal development of combination anti-vascular regimens requires the identification of those patients most likely to benefit from treatment with this class of drugs. Despite attempts, this goal has eluded us. In this study, we review the use of candidate predictive and/or pharmacodynamic biomarkers pertinent to VEGF inhibition and highlight approaches that are yet to be investigated.

\section{BIOMARKERS}

A biomarker is a characteristic that is objectively measured and evaluated as an indicator of a normal biological process, a pathogenic process or of pharmacological response to a therapeutic intervention (Atkinson et al, 2001). Several categories of biomarkers have been described that are pertinent to cancer, namely screening, diagnostic, prognostic, predictive, pharmacological (pharmacodynamic, proof of mechanism and of concept), surrogate response and safety biomarkers. Biomarker assays need to be carefully validated and be robust, reliable and reproducible when applied in clinical contexts. As VEGF inhibitors are already licensed, the most important question to be addressed using biomarkers is who should be treated with this class of agent; that is, at this point in the development of VEGF inhibitors, there is a clear need to identify predictive, pharmacological and surrogate response biomarkers, and in particular, to discriminate between these and prognostic biomarkers (which inform on the progression of disease irrespective of treatment).

A number of confounding issues recur in the literature regarding the use of biomarkers: Are there enough samples from sufficiently large trials to detect a statistically significant result? Have assays been performed within each patient before drug administration to determine whether a change in a biomarker can be ascribed to the drug, that is, is baseline variation characterised? Have biomarker studies been carried out according to the standards of Good Clinical Laboratory Practice required by the EU clinical trial directive (2001/20/EC). Such issues are of greater than theoretical importance, as, for example, we know that inappropriate blood sample handling can lead to platelet activation and ex vivo release of PDGF and VEGF. Therefore, debate is ongoing regarding the optimal choice of specimen for the measurement of these biomarkers. Serum seems to be a popular choice; however, the release of the above factors during clotting can influence the values measured. However, considering the low sensitivity of ELISAs to detect plasma levels and the proposed scavenging of VEGF by platelets (George et al, 2000), serum levels might represent the truer picture. In this study, we discuss trials that have incorporated circulating molecular and cellular, tissue, genetic and/or imaging biomarkers that are related to VEGF and its inhibition. Hypertension is one of the most common toxicities in patients having VEGF inhibitors and, in this study, we also examine the differential benefits seen in patients experiencing hypertension.

\section{CIRCULATING CANDIDATE BIOMARKERS OF ANGIOGENESIS}

The majority of clinical trials that have evaluated VEGF inhibitors have involved investigation of either anti-VEGF antibodies or VEGFR TKis. The prototypic VEGF inhibitor is the monoclonal anti-VEGF antibody, bevacizumab. Table 2a summarises the data collected from studies of circulating biomarkers in cancer patients treated with bevacizumab and other antibody-based therapeutics. One of the first biomarkers to be evaluated was the plasma concentration of VEGF-A. However, of multiple trials, only the E4599 trial in non-small-cell lung cancer reported that the pretreatment plasma concentration of VEGF was of prognostic significance (Dowlati et al, 2008). Intuitively, one would predict that the pre-treatment plasma concentration of VEGF would be most helpful in diseases that respond to single-agent VEGF inhibitors (e.g., renal, ovarian and hepatic cancer). However, the extent to which we can interpret such data is limited by, for example, studies that have been too small (Siegel et al, 2008) or in cases in which the limit of quantitation of ELISA was at a concentration that precluded interpretation of a significant proportion of biomarker data (Yang et al, 2003).

The initial phase I trials of anti-VEGF antibodies demonstrated that there was a logarithmic increase in the total plasma concentration of VEGF after drug administration (Gordon et al, 2001; Jayson et al, 2005). The source of this cytokine is not clear, but could reflect extensive loading of the extracellular matrix with VEGF in patients with advanced cancer. Thus, one hypothesis would be that the magnitude of the anti-VEGF antibody-induced change in plasma VEGF concentration might predict patient benefit. However, despite an interesting report in one small study (Siegel et al, 2008), this has not been confirmed in other trials, many of which were also compromised by their insufficient size. The other possibility is that anti-VEGF antibodies form inert complexes, causing a false increase in circulating VEGF levels. One study conducted using immunodepleted plasma has supported this assumption by showing a significant decrease in VEGF levels after treatment with bevacizumab (Loupakis et al, 2007). 
The increase in plasma VEGF concentration in patients treated with anti-VEGF antibodies has also been seen in those receiving low-molecular-weight VEGFR TKis (Table 2b). A VEGFR TKi biomarker signature has emerged, in which the drugs induce an increase in plasma VEGF and PlGF, as well as reductions in soluble VEGFR-2 and VEGFR-3. Presumably, this biomarker signature reflects the larger repertoire of receptors targeted by VEGFR TKis compared with anti-VEGF antibodies. If true, one might not expect to see an increase in VEGFR-3 concentrations in patients receiving bevacizumab, although this has not been formally reported.

Although a principal aim of biomarker studies in patients receiving VEGF inhibitors is to identify those patients who are most likely to benefit, it is equally important to detect the onset of drug resistance and ideally the factors mediating this resistance, which is an area of increasing importance, given recent data that indicate the potential value of continuing treatment with VEGF inhibitors until disease progression (Hurwitz et al, 2004; Saltz et al, 2008). To date, few biomarker studies have identified clinically tractable mediators of resistance, but some recent data highlighted FGF-2 and SDF- $1 \alpha$ as potential targets (Batchelor et al, 2007).

Circulating ECs (CECs) are believed to arise from vessel walls, either of mature vessels or the tumour vasculature. A subset of them is thought to originate from the bone marrow and represents circulating endothelial progenitor cells (CEPCs) (Lin et al, 2000). Normal adults have 1-20 CECs per $\mathrm{ml}$ in their peripheral blood, and the levels are shown to increase significantly in patients with advanced cancer (Rowand et al, 2007). After successful treatment, their concentration tends to normalise (Willett et al, 2005), in contrast to the situation in progressive disease (Beerepoot et al, 2004). In patients with breast cancer, one study demonstrated that the pre-treatment high concentration of CECs was a good prognostic factor (Dellapasqua et al, 2008), whereas another showed that in patients receiving metronomic doses of cytotoxic chemotherapy, an increase in circulating apoptotic CECs was associated with a better outcome (Mancuso et al, 2006).

Very few studies have evaluated changes in the number of CECs and CEPCs in the peripheral blood of patients receiving VEGF inhibitors. In general, CEC concentrations decrease after administration of VEGF inhibitors (Table 2a and 2b). However, this is not a consistent observation. When patients with rectal cancer were treated with bevacizumab, the concentration of CECs reduced (Willett et al, 2005), whereas in patients with gastrointestinal stromal tumour treated with sunitinib (a broad spectrum receptor TKi that inhibits c-kit and VEGFR), there was a transient increase in CECs that was associated with a better outcome (Norden-Zfoni et al, 2007).

Only a few studies have enumerated the number of CECs and CEPCs in the circulation of patients receiving VEGF inhibitors. However, significant methodological problems have to be overcome before these biomarkers can be incorporated routinely into multi-centre trials. To date, repeated pre-treatment samples have not been collected and therefore confidence intervals for individuals have not been clearly established, obscuring decisions with regard to treatment-induced effects. These problems are

Table 2a Anti-VEGF antibodies and circulating biomarkers

\begin{tabular}{|c|c|c|c|c|c|}
\hline References & Drug, disease and trial & Biomarkers & $\mathbf{N}$ & Drug-induced changes & Prognostic and predictive values \\
\hline Dowlati et al (2008) & $\begin{array}{l}\text { Carboplatin and Paclitaxel } \pm \\
\text { Bevacizumab } \\
\text { NSCLC (E4599); Phase } 2 / 3\end{array}$ & $\begin{array}{l}\text { VEGF } \\
\text { E-selectin } \\
\text { FGF-2 } \\
\text { ICAM }\end{array}$ & 160 & $\begin{array}{l}\downarrow \text { E-selectin } \\
\uparrow F G F-2\end{array}$ & $\begin{array}{l}\text { Baseline VEGF predicts response }(P=0.01) \\
\text {-Low baseline VEGF: better PFS }(P=0.04) \\
\text {-Low ICAM: better OS }(P=0.00005), 1 \\
\text { year survival and high RR }(P=0.02)\end{array}$ \\
\hline Siegel et al (2008) & $\begin{array}{l}\text { Bevacizumab } \\
\text { Unresectable HCC } \\
\text { Phase } 2\end{array}$ & $\begin{array}{l}\text { VEGF } \\
\text { SDF-I } \\
\text { HUVEC }\end{array}$ & 8 & $\begin{array}{l}\downarrow \text { VEGF and SDF- I } \\
\downarrow \text { HuVEC angiogenic score }\end{array}$ & $\begin{array}{l}\uparrow V E G F \text { and SDF-I on progression } \\
\text {-VEGF and SDF-I levels correlate with } \\
\text { angiogenic score }\end{array}$ \\
\hline Yang et al (2003) & Bevacizumab mRCC; Phase 2 & VEGF & 113 & $\uparrow$ VEGF & NS \\
\hline Nimeiri et al (2008) & $\begin{array}{l}\text { Bevacizumab+Erlotinib } \\
\text { Recurrent ovarian cancer } \\
\text { Phase } 2\end{array}$ & $\begin{array}{l}\text { sVEGFR-2 } \\
\text { Urine VEGF }\end{array}$ & | | & NS & NS \\
\hline Ko et al (2008) & $\begin{array}{l}\text { Gemcitabine+Cisplatin+Bevacizumab } \\
\text { Pancreatic cancer; Phase } 2\end{array}$ & $\begin{array}{l}\text { VEGF } \\
\text { FGF-2 }\end{array}$ & 46 & $\begin{array}{l}\uparrow \text { VEGF } \\
\uparrow F G F-2\end{array}$ & NS \\
\hline Garcia et al (2008) & $\begin{array}{l}\text { Cyclophosphamide+Bevacizumab } \\
\text { Ovarian cancer; Phase } 2\end{array}$ & $\begin{array}{l}\text { VEGF } \\
\text { E-selectin } \\
\text { TSP-I }\end{array}$ & 70 & $\uparrow$ VEGF and $\downarrow$ TSP- $\mid$ & NS \\
\hline $\begin{array}{l}\text { Denduluri et al } \\
\text { (2008) }\end{array}$ & $\begin{array}{l}\text { Bevacizumab } \\
\text { Breast cancer } \\
\text { Pilot study }\end{array}$ & $\begin{array}{l}\text { VEGF } \\
\text { sVCAM-I sVEGFR- } \\
2\end{array}$ & 21 & $\begin{array}{l}\uparrow s \vee C A M-1 \\
\uparrow s \vee E G F R-2\end{array}$ & NS \\
\hline Varker et al (2007) & $\begin{array}{l}\text { Bevacizumab } \pm \text { IFN } \alpha-2 b \\
\text { Malignant melanoma } \\
\text { Phase } 2\end{array}$ & $\begin{array}{l}\text { VEGF } \\
\text { FGF-2 }\end{array}$ & 32 & NS & NS \\
\hline Yao et al (2008) & $\begin{array}{l}\text { Octreotide }+ \text { INF } \alpha-2 b+ \\
\text { Bevacizumab } \\
\text { NET; Phase } 2\end{array}$ & $\begin{array}{l}\text { FGF-2 } \\
\text { IL-8 }\end{array}$ & 36 & $\begin{array}{l}\downarrow F G F-2 \\
\uparrow I L-8\end{array}$ & NS \\
\hline Jayson et al (2005) & $\begin{array}{l}\text { HuMV833 } \\
\text { Advanced cancer } \\
\text { Phase I }\end{array}$ & $\begin{array}{l}\text { VEGFR-I, IL-8, } \\
\text { sVCAM-I, FGF-2, } \\
\text { E-selectin, HGF }\end{array}$ & 20 & $\begin{array}{l}\uparrow \vee E G F \\
\downarrow F G F, H G F\end{array}$ & NS \\
\hline $\begin{array}{l}\text { Dellapasqua et al } \\
\text { (2008) }\end{array}$ & $\begin{array}{l}\text { Cyclophosphamide }+ \text { Capecitabine+ } \\
\text { Bevacizumab } \\
\text { Breast cancer; Phase } 2\end{array}$ & $\begin{array}{l}\text { CEC } \\
\text { CEPC }\end{array}$ & 46 & $\downarrow C E C$ & $\begin{array}{l}\text { High baseline CECs correlate with OR } \\
(P=0.02) \text {, clinical benefit }(P=0.01) \text { and } \\
\text { improved PFS }(P=0.04)\end{array}$ \\
\hline Willett et al (2005) & $\begin{array}{l}\text { Chemoradiotherapy+Bevacizumab } \\
\text { Rectal cancer; Phase I }\end{array}$ & $\begin{array}{l}\text { CEC } \\
\text { CEPC }\end{array}$ & 6 & $\downarrow$ CEC/CEPC & NS \\
\hline
\end{tabular}

Abbreviations: VEGF = vascular endothelial growth factor; CEC = circulating endothelial cell; CEPC = circulating endothelial progenitor cell; FGF-2 = fibroblast growth factor-2; $\mathrm{HCC}=$ hepatocellular carcinoma; HGF = hepatocyte growth factor; HUVEC = human umbilical vein endothelial cell; ICAM=intercellular adhesion molecule; INF $\boldsymbol{\alpha}$ $2 b=$ interferon $\alpha-2 b ; m R C C=$ metastatic renal cell carcinoma; NET = neuroendocrine tumour; NS = not significant; NSCLC $=$ non-small-cell lung cancer; OR $=$ overall response; $\mathrm{OS}=$ overall survival; $\mathrm{RR}=$ response rate; $\mathrm{SDF}-\mathrm{I}=$ stromal cell-derived factor-I; sVCAM=soluble vascular cell adhesion molecule; sVEGFR-2 = soluble VEGF receptor 2; TSP-I = thrombospondin- I. 


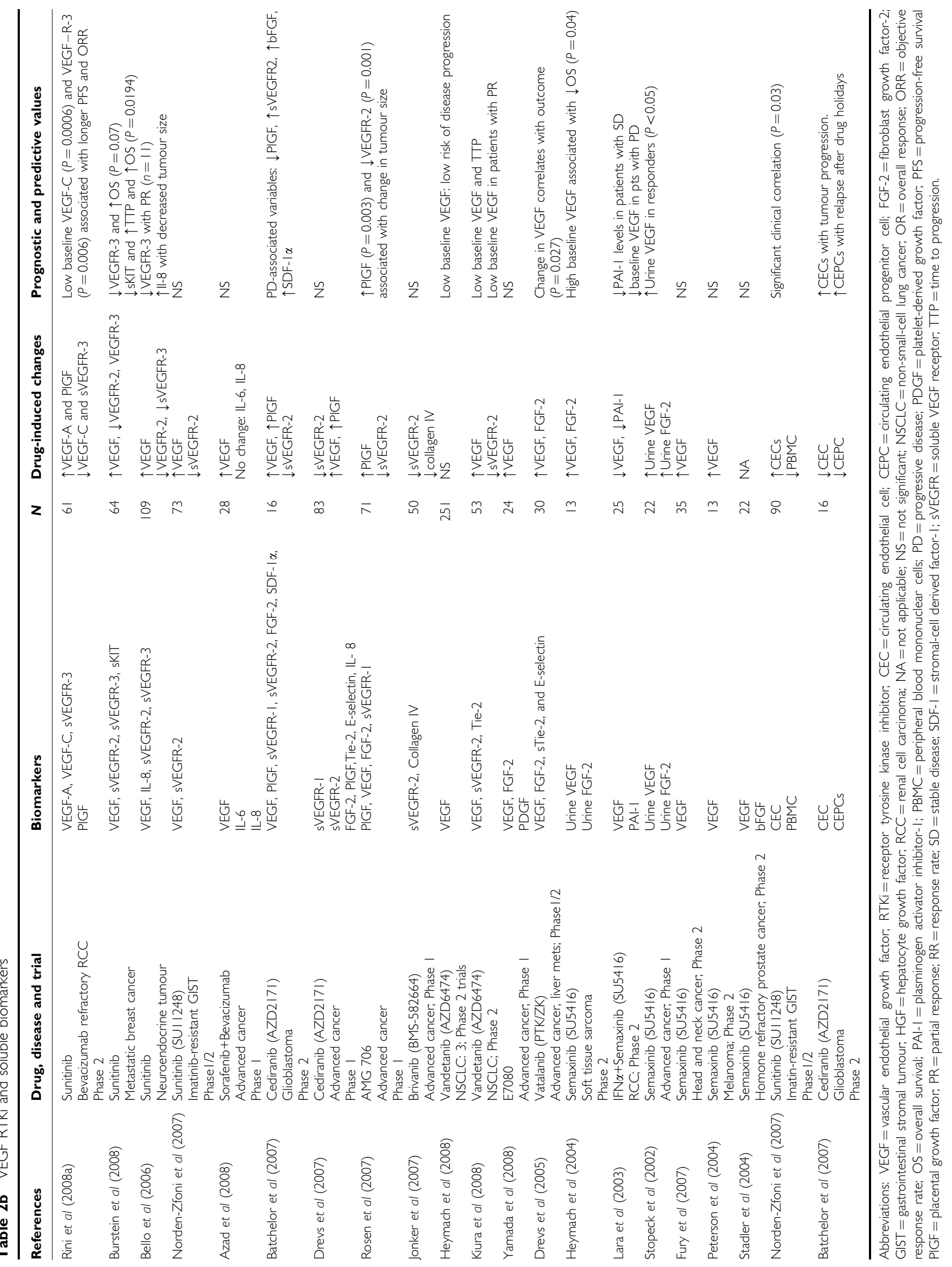


compounded by multiple platforms and antigen-selection suites (Mutin et al, 1999; Mancuso et al, 2001; Rowand et al, 2007; Dellapasqua et al, 2008) used to characterise CECs/CEPCs. The common technique used for analysis is immunomagnetic bead isolation or immunophenotyping using the flow cytometer. However, there is a lack of consensus regarding the choice of markers to be used. Real-time PCR using CD146 mRNA has been proposed as an alternative method for enumerating CECs (Furstenberger et al, 2005). At present, no markers are considered specific for CECs and a clearer antigen profile is required for isolating these cells.

In summary, the studies in Tables $2 a$ and $2 b$ identify a biomarker signature observed in patients treated with VEGF inhibitors. This includes an increase in VEGF (with or without VEGF-C), a decrease in VEGFR-2 (and sometimes in VEGFR-3) and, in some studies, a decrease in CECs. Occasionally, these biomarker changes have been of prognostic significance but none have been qualified as having predictive value. Although it is possible that the predictive potential of these biomarkers has not been tested in appropriately designed studies, it is important to note that many of the early studies focused on drugs with relatively high $\mathrm{IC}_{50}$ (e.g., semaxanib, SU5416), which therefore were less potent and perhaps less effective than the VEGFR TKis currently in the clinic, thereby reducing the chances of measuring a change in biomarker concentration on drugs that had more rapid clearance (e.g., vatalanib, PTK/ZK) or on trials that were too small to generate statistically significant results.

\section{IMAGING BIOMARKERS FOR VEGF INHIBITORS}

Conventional radiological reporting systems for new drugs rely on one-dimensional (Response Evaluation Criteria in Solid Tumours) or two-dimensional (WHO criteria) response-assessment schemes. Neither is well suited to the assessment of anti-angiogenic agents, the principal effect of which is tumour cytostasis. Thus, early clinical trials of VEGF inhibitors sought pharmacological proof of concept by examining changes in the tumour vasculature, predominantly through the use of MRI, which is a technology that is non-invasive, sensitive and avoids ionising radiation.

Of all the biomarkers that have been tested in trials of VEGF inhibitors, the most consistent findings have been achieved with dynamic contrast-enhanced MRI (DCE-MRI), in keeping with the proposed mechanism of action of the drugs (Tables $3 \mathrm{a}$ and $3 \mathrm{~b}$ ). Transfer constants such as $\mathrm{K}^{\text {trans }}$, a composite of the vascular permeability and endothelial surface area, are reduced in patients receiving VEGF inhibitors, and multiple studies have demonstrated a dose level-response relationship. In addition, a second relationship, the correlation between the magnitude of reduction in transfer constants and the attainment of stable or better disease, has been widely reported (Morgan et al, 2003; Mross et al, 2005; Thomas et al, 2005; Hahn et al, 2008). Although many of these studies were small and confounded by inter-patient heterogeneity; generally data show that patients whose tumours undergo at least a $50 \%$ reduction in DCE-MRI parameters attain stable or better disease. Thus, DCE-MRI perhaps holds the greatest promise as a prognostic and/or predictive biomarker for VEGF inhibitors, and recent data have highlighted the potential of another DCE-MRIderived parameter, $\mathrm{v}_{\mathrm{p}}$ (the fractional plasma volume), as a further candidate biomarker that may show clinical utility in trials of VEGF inhibitors (Hahn et al, 2008).

Dynamic contrast-enhanced MRI is more complex than computed tomography (CT) in terms of the ease with which it can be incorporated into multi-site studies; for this reason, many centres are testing the relationship between dynamic CT and DCE-MRI. On the basis of prognostic data gathered from analysis of the tumour vasculature seen in CT scans of patients with advanced ovarian cancer treated with conventional cytotoxic therapy (O'Connor et al, 2007), together with ongoing comparisons between dynamic CT and DCE-MRI, it is likely that there will be an expansion in research to assess whether these techniques can serve as predictive biomarkers in patients treated with VEGF inhibitors.

Recent interest in MRI techniques that do not require contrast has highlighted blood oxygenation level-dependent (BOLD) imaging and arterial spin labelling (ASL) (de Bazelaire et al, 2008). Arterial spin labelling, a technique in which protons entering the zone of interest are magnetised, was developed for imaging the vasculature of the brain. Although initial results with ASL in bodies of patients treated with VEGF inhibitors show promise as a prognostic biomarker (de Bazelaire et al, 2008), ASL is technically challenging when used to image the body and usually requires 3-T MRI machines. Blood oxygenation level-dependent imaging, a technique that relies on the paramagnetic effects of deoxyhaemoglobin, can be used to provide information on the oxygenation status of the patient's tumour, and in particular the oxygen status in tumour vessels. However, although anatomical resolution is good, the signal-to-noise ratio is relatively low and, although this can be increased by administering carbogen, such a procedure can be unpleasant for the patient (Padhani et al, 2007). Arterial spin labelling and BOLD are both attractive techniques, but have not been fully evaluated as biomarkers for VEGF inhibitors and for now are likely to remain confined to specialist imaging centres.

Hypoxia is a key mediator of angiogenesis, at least in part because it induces the expression of VEGF. However, there have been very few attempts to use hypoxia-imaging strategies as biomarkers for VEGF. In addition to BOLD, which has not been used to evaluate VEGF inhibitors in the clinic, positron emission tomography (PET) imaging tracers have been used to image hypoxia in the clinic. Both ${ }^{18} \mathrm{~F}$-MISO, which is retained in hypoxic cells through electron transfer that prevents egress from cells, and ${ }^{60} \mathrm{Cu}$-ATSM, which is retained through mechanisms that are unclear but depend on the redox state of cells, have been used to image hypoxia (Padhani et al, 2007). No studies have been reported to date on the imaging of hypoxia using these tracers in

Table 3a Antibody-based VEGFi and imaging biomarkers

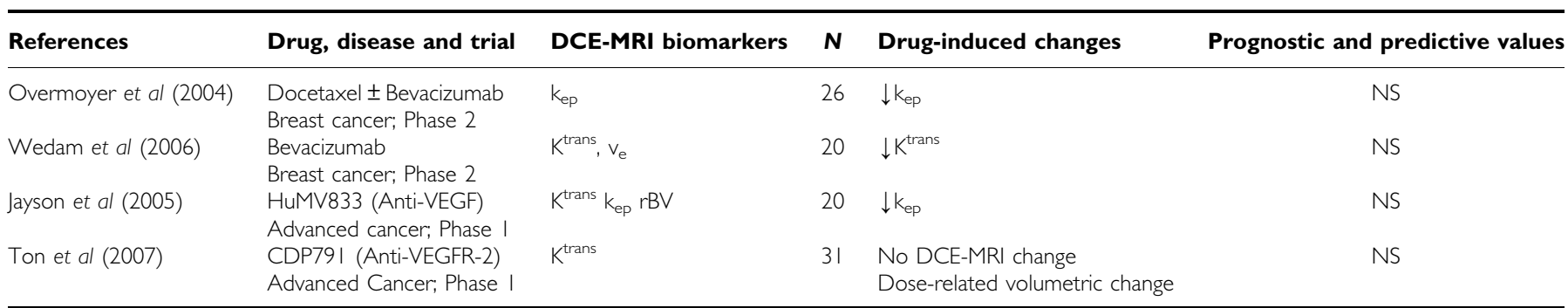

Abbreviations: VEGF = vascular endothelial growth factor; DCE-MRI = dynamic contrast-enhanced magnetic resonance imaging; $k_{e p}=$ rate constant; $K^{\text {trans }}=$ bi-directional transfer coefficient; $r B V=$ regional blood volume; $v_{e}=$ volume of the extravascular extracellular space (EES). 
Table 3b VEGFR, TKi and imaging biomarkers

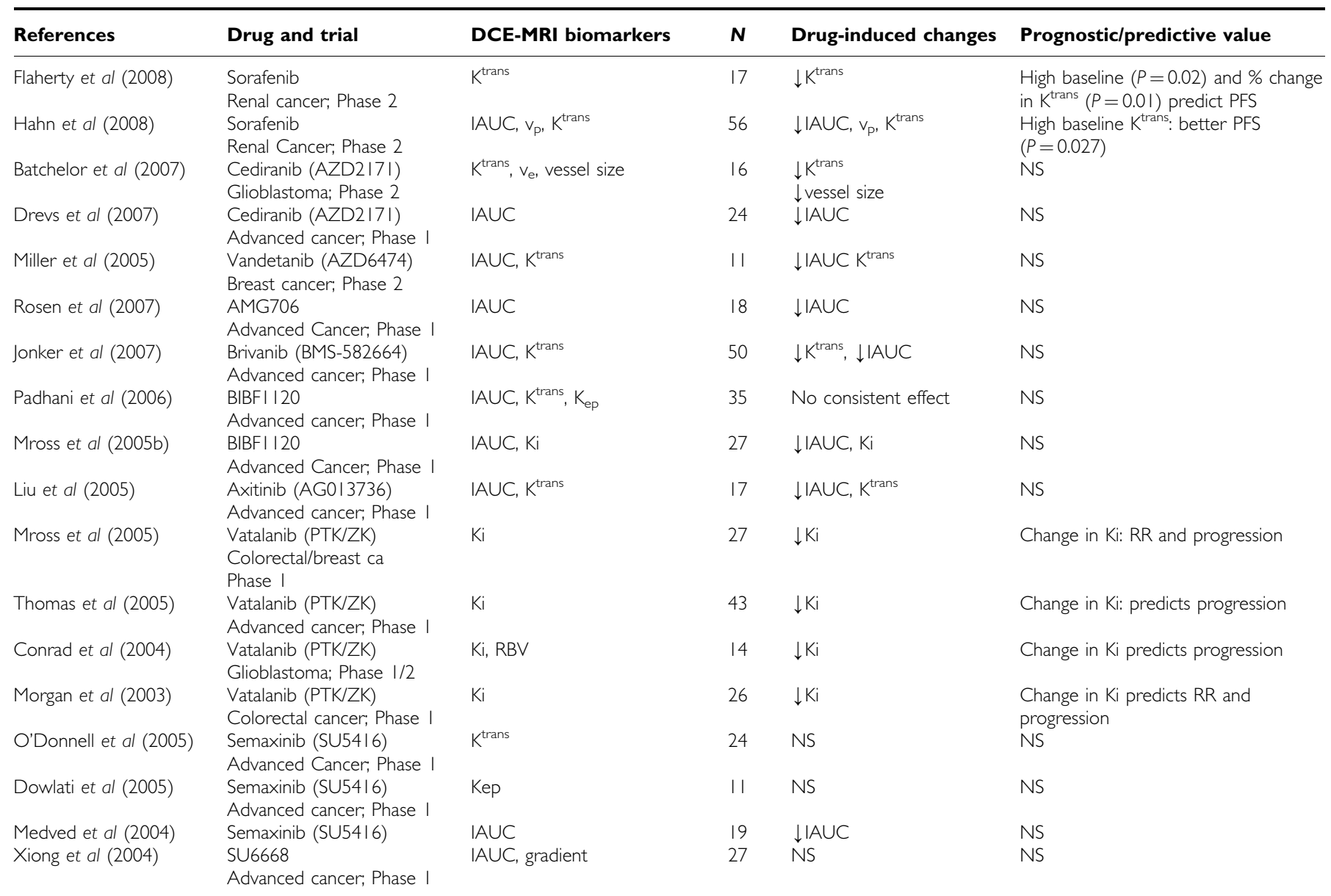

Abbreviations: VEGF = vascular endothelial growth factor; DCE-MRI = dynamic contrast-enhanced magnetic resonance imaging; IAUC = initial area under the contrast agent concentration - time curve; $K_{i}=$ unidirectional influx constant; $\mathrm{K}_{\mathrm{ep}}=$ rate constant; $\mathrm{k}^{\text {trans }}=$ bi-directional transfer coefficient; $\mathrm{NS}=$ not significant; $r \mathrm{BV}=$ regional blood volume; $\mathrm{RR}=$ response rate; $\mathrm{v}_{\mathrm{e}}=$ volume of the extravascular extracellular space; $\mathrm{v}_{\mathrm{p}}=$ blood plasma volume.

patients treated with VEGF inhibitors. The PET perfusion tracer, ${ }^{15} \mathrm{O}-\mathrm{H}_{2} \mathrm{O}$, has also not been investigated in this setting.

The most widely used PET tracer, ${ }^{18} \mathrm{~F}-\mathrm{FDG}$, has only been evaluated in small series in patients treated with VEGF inhibitors. In patients with rectal cancer (Willett et al, 2004), administration of bevacizumab did not change FDG uptake over a 12-day period, despite positive pharmacological proof-of-principle studies conducted during this time period. This lack of effect has not been explained but could be due to the upregulation of the glucose transporter in hypoxic cells. Thus, if bevacizumab increases tumour cell hypoxia, paradoxically, one might observe either no change or an increase in FDG uptake.

In place of ${ }^{18} \mathrm{~F}$-FDG, recent interest has focused on ${ }^{18} \mathrm{~F}$-fluorothymidine $\left({ }^{18} \mathrm{~F}-\mathrm{FLT}\right)$, which is incorporated into newly synthesised DNA and is taken as a surrogate for cellular proliferation. In both primary and metastatic colorectal cancer, $\left[{ }^{18} \mathrm{~F}\right] \mathrm{FLT}$ uptake (SUV) correlates with proliferative activity, as determined by MIB-1 immunohistochemistry (Francis et al, 2003). Interestingly, changes in ${ }^{18}$ F-FLT uptake were associated with OS in patients with malignant gliomas treated with combination of irinotecan and bevacizumab (Chen et al, 2007; Sohn et al, 2008). An important confounding factor for future studies is that effective antiangiogenic therapy impairs blood vessel function and tumour perfusion. Unless detailed dynamic studies of tracer uptake are conducted to take this factor into account, there is a risk that SUV analysis of ${ }^{18}$ F-FLT in patients will overestimate the anti- proliferative effects of VEGF inhibitors. Nevertheless, this is the only PET tracer that has yielded potentially useful data with VEGF inhibitors and further exploration is warranted to determine whether it can be used as a predictive biomarker.

In summary, the most promising candidate biomarkers for VEGF inhibition arise from DCE-MRI evaluation of the effect of VEGF inhibitors in solid tumours. The relationships between dose level and MRI effect and between MRI effect and clinical benefit highlight the potential for such imaging to be evaluated as predictive biomarkers. In particular, the observation that patients whose tumours undergo a $>50 \%$ reduction in contrast uptake or transfer constants in response to VEGF inhibitors usually attain stable or better disease, thus leading to the following questions regarding patient management: If we know that patients attaining $50 \%$ reduction in DCE-MRI parameters benefit from the drug, can we escalate the drug dose until this end point is reached? If dose escalation attains this degree of DCE-MRI effect, will it result in clinical benefit? Correspondingly, in patients who do not achieve $50 \%$ reduction in DCE-MRI parameters, should we stop the VEGF inhibitors?

\section{TISSUE BIOMARKERS FOR VEGF INHIBITORS}

The majority of cancer diagnoses are achieved through light microscopic and immunohistochemical characterisation of the 
malignant tissue. Therefore, the availability of these blocks is a factor to be considered while looking for predictive biomarkers for VEGF inhibitors, accepting the caveat that the small proportion of tumours examined in such studies may not be representative of the whole cancer burden. For at least 10 years, multiple studies have reported the relationship between microvessel density (MVD), the product of angiogenesis and metastasis, and survival in solid tumours (Hasan et al, 2002). As the principal receptor implicated in driving angiogenesis was VEGFR-2, it was logical to test the value of MVD, VEGFR-2 and phospho-VEGFR2 as potential predictive biomarkers for VEGF inhibitors. Despite incorporation into multiple studies, these trials have largely been unable to confirm the hypothesis (e.g., Jubb et al (2006)), although some smaller studies (Yang et al, 2008) have reported a relationship between MVD (based on CD31) and positive response. Putative explanations for the lack of predictive value of MVD have focused on the lack of congruence between tumour metabolism, perfusion, growth and vessel density in clinical studies (Hlatky et al, 2002). As an alternative, various groups have used EC proliferation measured by double-staining techniques as an indicator of angiogenesis (Hillen et al, 2006; Wedam et al, 2006). Although a prognostic association was observed in melanoma, their role as a potential biomarker for VEGF inhibitors needs to be investigated further. More recent in vivo data have demonstrated that multiple cellular lineages, such as myeloid (Shojaei et al, 2007) and mesenchymal (Crawford et al, 2009) cells, present in and around new blood vessels can modulate sensitivity to VEGF inhibitors. Thus, more detailed cell biological studies of blood vessels in tumours may be required to determine the potential biomarker value of MVD.

Perhaps the most attractive tissue biomarker that could serve in a predictive capacity is phospho-VEGFR-2. In patients with inflammatory breast carcinoma, administration of bevacizumab resulted in significantly reduced phospho-VEGFR-2. This was coupled with a marked increase in tumour cell apoptosis, but no significant change in proliferation (Wedam et al, 2006). In a phase I trial of a VEGFR-2-binding di-Fab fragment, biopsy data were compatible with the proposed mechanism of action (Ton et al, 2007). However, such reports are very infrequent for at least two reasons: processing tissues from patients to detect phospho-proteins requires extremely rapid tissue preservation to avoid de-phosphorylation of receptors. Second, there are very few antibodies that bind with sufficient specificity to phospho-VEGFR2. Whether a validated biomarker assay of anti-phospho-VEGFR-2 could be used successfully in a multi-site study remains to be established.

\section{GENETIC BIOMARKERS FOR VEGF INHIBITORS}

Angiogenesis is a host-mediated phenomenon (Ferrara, 2001) in which the heterogeneous response to VEGF inhibitors may be related to inherited variations in genes coding for products that regulate angiogenesis.

Few studies have reported an association between clinical outcome and single-nucleotide polymorphisms (SNPs) in genes for VEGF. When patients with metastatic breast cancer were treated with paclitaxel and bevacizumab (E2100 trial), SNP analysis demonstrated that VEGF-2578 AA and VEGF 1154-A genotypes were associated with better OS but not response rate (RR) or PFS (Schneider et al, 2008). In contrast, those patients who received bevacizumab had a better RR and PFS but not OS, thereby challenging the pathophysiological role of these SNPs with regard to bevacizumab efficacy.

Multiple genes affect the efficacy of VEGF inhibitors. In patients with ovarian cancer who received cyclophosphamide and bevacizumab (Schultheis et al, 2008), those with an A/A or A/T genotype for Il-8 T-251A attained a lower RR than did those with a homozygous $\mathrm{T} / \mathrm{T}$ genotype $(P=0.006)$. The study also showed an association between PFS and polymorphisms involving CXCR2 $\mathrm{C}+785 \mathrm{~T} \quad(P=0.026)$, VEGF $\mathrm{C}+936 \mathrm{~T} \quad(P=0.061)$ and adreno medullin dinucleotide repeat polymorphisms $(P=0.008)$. Although of initial interest, these findings should be explored in further prospective trials and it will be important to define the structure-function relationships for particular variants that are associated with a better or worse prognosis.

\section{HYPERTENSION AS A BIOMARKER OF RESPONSE}

Hypertension is one of the most common toxicities in patients taking VEGF inhibitors. The Hurwitz paper reported an overall incidence of $22.4 \%$, with $11 \%$ developing grade 3 hypertension (Hurwitz et al, 2004). In general, the level of hypertension is doselevel related, although the exact mechanism remains unexplained. One hypothesis is that VEGF signalling regulates nitric oxide synthase. Thus, VEGF inhibitors reduce the synthesis of nitric oxide, increasing vasoconstriction and therefore hypertension. If this is the case, then hypothetically (Maitland et al, 2006), an increase in blood pressure should reflect successful inhibition of the VEGF pathway. Multiple trials have corroborated this hypothesis: Of 39 patients receiving irinotecan, fluorouracil and bevacizumab for metastatic colorectal cancer, the RR and PFS (median: 14.5 vs 3.1 months, $P=0.04$ ) were significantly better for patients who had bevacizumab-induced grade 2-3 hypertension (Scartozzi et al, 2009). In the E2100 study on advanced breast cancer, patients who experienced grade 3 or 4 hypertension survived significantly longer (38.7 vs 25.3 months, $P=0.002$ ), although hypertension was seen in patients with VEGF634CC and VEGF1498TT genotypes (Schneider et al, 2008). A retrospective study involving multiple tumour types treated with axitinib, an oral VEGF inhibitor, has shown an association between diastolic blood pressure of $\geqslant 90 \mathrm{~mm} \mathrm{Hg}$ and survival (O. Rixe et al, 2008; Rini et al, 2008b).

Vascular endothelial growth factor inhibitor-induced hypertension seems to show dose level-dependent effects and therefore, as proposed for DCE-MRI, it is appropriate to ask whether we should increase the dose of VEGF inhibitors, if tolerated, until we observe hypertension.

\section{FUTURE DIRECTIONS}

The above data identify DCE-MRI, particular circulating parameters (VEGF and VEGFR2) and hypertension as candidate prognostic biomarkers for VEGF. It is now important to assess these candidates on the basis of various parameters. First, highquality biomarker studies should be conducted to test the predictive value of these candidate biomarkers when carried out using GCLP-validated assays in optimised clinical trial designs. Second, we should test the biomarker hypothesis in a randomised trial setting, which is that dose escalation until one of these parameters is significantly perturbed will optimise treatment and lead to better outcome. If this is possible, then which of the biomarkers should be the target against which we should escalate dose? If escalation does not increase the change in biomarker, then should the drug be discontinued?

Certain biomarkers have not been evaluated in patients receiving VEGF inhibitors, the most important of which is the imaging biomarkers of hypoxia. Interesting recent pre-clinical data have highlighted the potential importance of measuring the concentration of circulating tumour cells, which depend critically on tumour circulation for intravasation, as potential biomarkers of VEGF inhibitors (Ebos et al, 2009; Paez-Ribes et al, 2009; Reynolds et al, 2009).

Vascular endothelial growth factor inhibitors have proven clinical value in multiple clinical settings. If we are to use these 
agents in the best way and, most critically, if we are to develop combination regimens that build on their efficacy, it is vital to identify who to treat using predictive biomarkers and with what dose and schedule, as determined by pharmacodynamic biomarkers. Strong biomarker research offers a realistic opportunity to address these pivotal questions.

\section{REFERENCES}

Achen MG, Jeltsch M, Kukk E, Makinen T, Vitali A, Wilks AF, Alitalo K, Stacker SA (1998) Vascular endothelial growth factor D (VEGF-D) is a ligand for the tyrosine kinases VEGF receptor 2 (Flk1) and VEGF receptor 3 (Flt4). Proc Natl Acad Sci USA 95: $548-553$

Atkinson AJ, Colburn WA, DeGruttola VG, DeMets DL, Downing GJ, Hoth DF, Oates JA, Peck CC, Schooley RT, Spilker BA, Woodcock J, Zeger SL (2001) Biomarkers and surrogate endpoints: preferred definitions and conceptual framework* Clin Pharmacol Ther 69: 89-95

Azad NS, Jain L, Annunziata C, Cao L, Greenberg L, Minasian L, Perroy A, Kotz H, Figg WD, Kohn E (2008) Correlative studies of a phase I trial of combination anti-vascular endothelial growth factor (VEGF) therapy with sorafenib and bevacizumab. J Clin Oncol 26: 2008 (20 May suppl; abstract 3545)

Batchelor TT, Sorensen AG, di Tomaso E, Zhang WT, Duda DG, Cohen KS, Kozak KR, Cahill DP, Chen PJ, Zhu M, Ancukiewicz M, Mrugala MM, Plotkin S, Drappatz J, Louis DN, Ivy P, Scadden DT, Benner T, Loeffler JS, Wen PY, Jain RK (2007) AZD2171, a pan-VEGF receptor tyrosine kinase inhibitor, normalizes tumor vasculature and alleviates edema in glioblastoma patients. Cancer Cell 11: 83-95

Bates DO, Cui TG, Doughty JM, Winkler M, Sugiono M, Shields JD, Peat D, Gillatt D, Harper SJ (2002) VEGF165b, an inhibitory splice variant of vascular endothelial growth factor, is down-regulated in renal cell carcinoma. Cancer Res 62: 4123-4131

Beerepoot LV, Mehra N, Vermaat JS, Zonnenberg BA, Gebbink MF, Voest EE (2004) Increased levels of viable circulating endothelial cells are an indicator of progressive disease in cancer patients. Ann Oncol 15: $139-145$

Bello C, Deprimo SE, Friece C, Smeraglia J, Sherman L, Tye L, Baum C, Meropol NJ, Lenz H, Kulke MH (2006) Analysis of circulating biomarkers of sunitinib maleate in patients with unresectable neuroendocrine tumors (NET): VEGF, IL-8, and soluble VEGF receptors 2 and 3. Proc Am Soc Clin Oncol 24: 4045a

Burstein HJ, Elias AD, Rugo HS, Cobleigh MA, Wolff AC, Eisenberg PD, Lehman M, Adams BJ, Bello CL, DePrimo SE, Baum CM, Miller KD (2008) Phase II study of sunitinib malate, an oral multitargeted tyrosine kinase inhibitor, in patients with metastatic breast cancer previously treated with an anthracycline and a taxane. J Clin Oncol 26: $1810-1816$

Carmeliet P, Moons L, Luttun A, Vincenti V, Compernolle V, De Mol M, Wu Y, Bono F, Devy L, Beck H, Scholz D, Acker T, DiPalma T, Dewerchin M, Noel A, Stalmans I, Barra A, Blacher S, Vandendriessche T, Ponten A, Eriksson U, Plate KH, Foidart JM, Schaper W, Charnock-Jones DS, Hicklin DJ, Herbert JM, Collen D, Persico MG (2001) Synergism between vascular endothelial growth factor and placental growth factor contributes to angiogenesis and plasma extravasation in pathological conditions. Nat Med 7: 575-583

Chen W, Delaloye S, Silverman DH, Geist C, Czernin J, Sayre J, Satyamurthy N, Pope W, Lai A, Phelps ME, Cloughesy T (2007) Predicting treatment response of malignant gliomas to bevacizumab and irinotecan by imaging proliferation with $[18 \mathrm{~F}]$ fluorothymidine positron emission tomography: a pilot study. J Clin Oncol 25: 4714-4721

Conrad C, Friedman H, Reardon D, Provenzale J, Jackson E, Serajuddin H, Laurent D, Chen B, Yung WKA (2004) A phase I/II trial of single-agent PTK 787/ZK 222584 (PTK/ZK), a novel, oral angiogenesis inhibitor, in patients with recurrent glioblastoma multiforme (GBM). J Clin Oncol (Meetings Abstracts) 22(14S): 1512

Crawford Y, Kasman I, Yu L, Zhong C, Wu X, Modrusan Z, Kaminker J, Ferrara N (2009) PDGF-C mediates the angiogenic and tumorigenic properties of fibroblasts associated with tumors refractory to anti-VEGF treatment. Cancer Cell 15: 21-34

de Bazelaire C, Alsop DC, George D, Pedrosa I, Wang Y, Michaelson MD, Rofsky NM (2008) Magnetic resonance imaging-measured blood flow change after antiangiogenic therapy with PTK787/ZK 222584 correlates with clinical outcome in metastatic renal cell carcinoma. Clin Cancer Res 14: $5548-5554$
Dellapasqua S, Bertolini F, Bagnardi V, Campagnoli E, Scarano E, Torrisi R, Shaked Y, Mancuso P, Goldhirsch A, Rocca A, Pietri E, Colleoni M (2008) Metronomic cyclophosphamide and capecitabine combined with bevacizumab in advanced breast cancer. J Clin Oncol 26: 4899-4905

Denduluri N, Yang SX, Berman AW, Nguyen D, Liewehr DJ, Steinberg SM, Swain SM (2008) Circulating biomarkers of bevacizumab activity in patients with breast cancer. Cancer Biol Ther 7: 15-20

Dowlati A, Gray R, Sandler AB, Schiller JH, Johnson DH (2008) Cell adhesion molecules, vascular endothelial growth factor, and basic fibroblast growth factor in patients with non-small cell lung cancer treated with chemotherapy with or without bevacizumab - an Eastern Cooperative Oncology Group Study. Clin Cancer Res 14: 1407-1412

Dowlati A, Robertson K, Radivoyevitch T, Waas J, Ziats NP, Hartman P, Abdul-Karim FW, Wasman JK, Jesberger J, Lewin J, McCrae K, Ivy P, Remick SC (2005) Novel phase I dose de-escalation design trial to determine the biological modulatory dose of the antiangiogenic agent SU5416. Clin Cancer Res 11: 7938-7944

Drevs J, Siegert P, Medinger M, Mross K, Strecker R, Zirrgiebel U, Harder J, Blum H, Robertson J, Jurgensmeier JM, Puchalski TA, Young H, Saunders O, Unger C (2007) Phase I clinical study of AZD2171, an oral vascular endothelial growth factor signaling inhibitor, in patients with advanced solid tumors. J Clin Oncol 25: 3045-3054

Drevs J, Zirrgiebel U, Schmidt-Gersbach CI, Mross K, Medinger M, Lee L, Pinheiro J, Wood J, Thomas AL, Unger C, Henry A, Steward WP, Laurent D, Lebwohl D, Dugan M, Marme D (2005) Soluble markers for the assessment of biological activity with PTK787/ZK 222584 (PTK/ZK), a vascular endothelial growth factor receptor (VEGFR) tyrosine kinase inhibitor in patients with advanced colorectal cancer from two phase I trials. Ann Oncol 16: 558-565

Ebos JM, Lee CR, Cruz-Munoz W, Bjarnason GA, Christensen JG, Kerbel RS (2009) Accelerated metastasis after short-term treatment with a potent inhibitor of tumor angiogenesis. Cancer Cell 15: 232-239

Ferrara N (2001) Role of vascular endothelial growth factor in regulation of physiological angiogenesis. Am J Physiol Cell Physiol 280: C1358-C1366

Flaherty KT, Rosen MA, Heitjan DF, Gallagher ML, Schwartz B, Schnall MD, O'Dwyer PJ (2008) Pilot study of DCE-MRI to predict progressionfree survival with sorafenib therapy in renal cell carcinoma. Cancer Biol Ther 7: 496-501

Francis DL, Freeman A, Visvikis D, Costa DC, Luthra SK, Novelli M, Taylor I, Ell PJ (2003) In vivo imaging of cellular proliferation in colorectal cancer using positron emission tomography. Gut 52: 1602-1606

Furstenberger G, von Moos R, Senn HJ, Boneberg EM (2005) Real-time PCR of CD146 mRNA in peripheral blood enables the relative quantification of circulating endothelial cells and is an indicator of angiogenesis. $\mathrm{Br} J$ Cancer 93: $793-798$

Fury MG, Zahalsky A, Wong R, Venkatraman E, Lis E, Hann L, Aliff T, Gerald W, Fleisher M, Pfister DG (2007) A phase II study of SU5416 in patients with advanced or recurrent head and neck cancers. Invest New Drugs 25: $165-172$

Garcia AA, Hirte H, Fleming G, Yang D, Tsao-Wei DD, Roman L, Groshen S, Swenson S, Markland F, Gandara D, Scudder S, Morgan R, Chen H, Lenz HJ, Oza AM (2008) Phase II clinical trial of bevacizumab and low-dose metronomic oral cyclophosphamide in recurrent ovarian cancer: a trial of the California, Chicago, and Princess Margaret Hospital phase II consortia. J Clin Oncol 26: 76-82

George ML, Eccles SA, Tutton MG, Abulafi AM, Swift RI (2000) Correlation of plasma and serum vascular endothelial growth factor levels with platelet count in colorectal cancer: clinical evidence of platelet scavenging? Clin Cancer Res 6: 3147-3152

Giantonio BJ, Catalano PJ, Meropol NJ, O’Dwyer PJ, Mitchell EP, Alberts SR, Schwartz MA, Benson III AB (2007) Bevacizumab in combination with oxaliplatin, fluorouracil, and leucovorin (FOLFOX4) for previously treated metastatic colorectal cancer: results from the eastern cooperative oncology group study E3200. J Clin Oncol 25: 1539-1544

Gordon MS, Margolin K, Talpaz M, Sledge Jr GW, Holmgren E, Benjamin R, Stalter S, Shak S, Adelman D (2001) Phase I safety and pharmacokinetic 
study of recombinant human anti-vascular endothelial growth factor in patients with advanced cancer. J Clin Oncol 19: 843-850

Hahn OM, Yang C, Medved M, Karczmar G, Kistner E, Karrison T, Manchen E, Mitchell M, Ratain MJ, Stadler WM (2008) Dynamic contrast-enhanced magnetic resonance imaging pharmacodynamic biomarker study of sorafenib in metastatic renal carcinoma. J Clin Oncol 26: $4572-4578$

Hanahan D, Folkman J (1996) Patterns and emerging mechanisms of the angiogenic switch during tumorigenesis. Cell 86: 353-364

Hasan J, Byers R, Jayson GC (2002) Intra-tumoural microvessel density in human solid tumours. Br J Cancer 86: 1566-1577

Heymach JV, Desai J, Manola J, Davis DW, McConkey DJ, Harmon D, Ryan DP, Goss G, Quigley T, Van den Abbeele AD, Silverman SG, Connors S, Folkman J, Fletcher CD, Demetri GD (2004) Phase II study of the antiangiogenic agent SU5416 in patients with advanced soft tissue sarcomas. Clin Cancer Res 10: $5732-5740$

Heymach JV, Hanrahan EO, Mann H, Langmuir P, Natale RB, Johnson BE, Herbst RS, Ryan AJ (2008) Baseline VEGF as a potential predictive biomarker of vandetanib clinical benefit in patients with advanced NSCLC. ASCO Meet Abstr 26: 8009

Hillen F, van de Winkel A, Creytens D, Vermeulen AH, Griffioen AW (2006) Proliferating endothelial cells, but not microvessel density, are a prognostic parameter in human cutaneous melanoma. Melanoma Res 16: $453-457$

Hlatky L, Hahnfeldt P, Folkman J (2002) Clinical application of antiangiogenic therapy: microvessel density, what it does and doesn't tell us. J Natl Cancer Inst 94: 883-893

Hurwitz H, Fehrenbacher L, Novotny W, Cartwright T, Hainsworth J, Heim W, Berlin J, Baron A, Griffing S, Holmgren E, Ferrara N, Fyfe G, Rogers B, Ross R, Kabbinavar F (2004) Bevacizumab plus irinotecan, fluorouracil, and leucovorin for metastatic colorectal cancer. $N$ Engl J Med 350: $2335-2342$

Jayson GC, Mulatero C, Ranson M, Zweit J, Jackson A, Broughton L, Wagstaff J, Hakansson L, Groenewegen G, Lawrance J, Tang M, Wauk L, Levitt D, Marreaud S, Lehmann FF, Herold M, Zwierzina H (2005) Phase I investigation of recombinant anti-human vascular endothelial growth factor antibody in patients with advanced cancer. Eur J Cancer 41: $555-563$

Jonker DJ, Rosen LS, Sawyer M, Wilding G, Noberasco C, Jayson G, Rustin G, McArthur G, Velasquez L, Galbraith S (2007) A phase I study of BMS-582664 (brivanib alaninate), an oral dual inhibitor of VEGFR and FGFR tyrosine kinases, in patients (pts) with advanced/metastatic solid tumors: safety, pharmacokinetic (PK), and pharmacodynamic (PD) findings. J Clin Oncol (Meeting Abstracts) 25: 3559

Joukov V, Pajusola K, Kaipainen A, Chilov D, Lahtinen I, Kukk E, Saksela O, Kalkkinen N, Alitalo K (1996) A novel vascular endothelial growth factor, VEGF-C, is a ligand for the Flt4 (VEGFR-3) and KDR (VEGFR-2) receptor tyrosine kinases. EMBO J 15: 290-298

Jubb AM, Hurwitz HI, Bai W, Holmgren EB, Tobin P, Guerrero AS, Kabbinavar F, Holden SN, Novotny WF, Frantz GD, Hillan KJ, Koeppen $\mathrm{H}$ (2006) Impact of vascular endothelial growth factor-A expression, thrombospondin-2 expression, and microvessel density on the treatment effect of bevacizumab in metastatic colorectal cancer. J Clin Oncol 24: $217-227$

Kawasaki T, Kitsukawa T, Bekku Y, Matsuda Y, Sanbo M, Yagi T, Fujisawa $\mathrm{H}$ (1999) A requirement for neuropilin-1 in embryonic vessel formation. Development 126: 4895-4902

Kiura K, Nakagawa K, Shinkai T, Eguchi K, Ohe Y, Yamamoto N, Tsuboi M, Yokota S, Seto T, Jiang H, Nishio K, Saijo N, Fukuoka M (2008) A randomized, double-blind, phase IIa dose-finding study of Vandetanib (ZD6474) in Japanese patients with non-small cell lung cancer. J Thorac Oncol 3: 386-393

Ko AH, Dito E, Schillinger B, Venook AP, Xu Z, Bergsland EK, Wong D, Scott J, Hwang J, Tempero MA (2008) A phase II study evaluating bevacizumab in combination with fixed-dose rate gemcitabine and lowdose cisplatin for metastatic pancreatic cancer: is an anti-VEGF strategy still applicable? Invest New Drugs 26: 463-471

Lara Jr PN, Quinn DI, Margolin K, Meyers FJ, Longmate J, Frankel P, Mack PC, Turrell C, Valk P, Rao J, Buckley P, Wun T, Gosselin R, Galvin I, Gumerlock PH, Lenz HJ, Doroshow JH, Gandara DR (2003) SU5416 plus interferon alpha in advanced renal cell carcinoma: a phase II California Cancer Consortium Study with biological and imaging correlates of angiogenesis inhibition. Clin Cancer Res 9: $4772-4781$
Lin Y, Weisdorf DJ, Solovey A, Hebbel RP (2000) Origins of circulating endothelial cells and endothelial outgrowth from blood. J Clin Invest 105: $71-77$

Liu G, Rugo HS, Wilding G, McShane TM, Evelhoch JL, Ng C, Jackson E, Kelcz F, Yeh BM, Lee Jr FT, Charnsangavej C, Park JW, Ashton EA, Steinfeldt HM, Pithavala YK, Reich SD, Herbst RS (2005) Dynamic contrast-enhanced magnetic resonance imaging as a pharmacodynamic measure of response after acute dosing of AG-013736, an oral angiogenesis inhibitor, in patients with advanced solid tumors: results from a phase I study. J Clin Oncol 23: $5464-5473$

Llovet JM, Ricci S, Mazzaferro V, Hilgard P, Gane E, Blanc JF, de Oliveira AC, Santoro A, Raoul JL, Forner A, Schwartz M, Porta C, Zeuzem S, Bolondi L, Greten TF, Galle PR, Seitz JF, Borbath I, Haussinger D, Giannaris T, Shan M, Moscovici M, Voliotis D, Bruix J (2008) Sorafenib in advanced hepatocellular carcinoma. $N$ Engl J Med 359: 378 - 390

Loupakis F, Falcone A, Masi G, Fioravanti A, Kerbel RS, Del Tacca M, Bocci G (2007) Vascular endothelial growth factor levels in immunodepleted plasma of cancer patients as a possible pharmacodynamic marker for bevacizumab activity. J Clin Oncol 25: 1816-1818

Maitland ML, Moshier K, Imperial J, Kasza KE, Karrison T, Elliott W, Undevia SD, Stadler W, Desai AA, Ratain MJ (2006) Blood pressure (BP) as a biomarker for sorafenib (S), an inhibitor of the vascular endothelial growth factor (VEGF) signaling pathway. J Clin Oncol (Meeting Abstracts) 24: 2035

Mancuso P, Burlini A, Pruneri G, Goldhirsch A, Martinelli G, Bertolini F (2001) Resting and activated endothelial cells are increased in the peripheral blood of cancer patients. Blood 97: 3658-3661

Mancuso P, Colleoni M, Calleri A, Orlando L, Maisonneuve P, Pruneri G, Agliano A, Goldhirsch A, Shaked Y, Kerbel RS, Bertolini F (2006) Circulating endothelial-cell kinetics and viability predict survival in breast cancer patients receiving metronomic chemotherapy. Blood 108: $452-459$

Medved M, Karczmar G, Yang C, Dignam J, Gajewski TF, Kindler H, Vokes E, MacEneany P, Mitchell MT, Stadler WM (2004) Semiquantitative analysis of dynamic contrast enhanced MRI in cancer patients: variability and changes in tumor tissue over time. J Magn Reson Imaging 20: $122-128$

Miller K, Wang M, Gralow J, Dickler M, Cobleigh M, Perez EA, Shenkier T, Cella D, Davidson NE (2007) Paclitaxel plus bevacizumab versus paclitaxel alone for metastatic breast cancer. $N$ Engl J Med 357: 2666 2676

Miller KD, Trigo JM, Wheeler C, Barge A, Rowbottom J, Sledge G, Baselga J (2005) A multicenter phase II trial of ZD6474, a vascular endothelial growth factor receptor-2 and epidermal growth factor receptor tyrosine kinase inhibitor, in patients with previously treated metastatic breast cancer. Clin Cancer Res 11: 3369-3376

Morgan B, Thomas AL, Drevs J, Hennig J, Buchert M, Jivan A, Horsfield MA, Mross K, Ball HA, Lee L, Mietlowski W, Fuxuis S, Unger C, O'Byrne K, Henry A, Cherryman GR, Laurent D, Dugan M, Marme D, Steward WP (2003) Dynamic contrast-enhanced magnetic resonance imaging as a biomarker for the pharmacological response of PTK787/ZK 222584, an inhibitor of the vascular endothelial growth factor receptor tyrosine kinases, in patients with advanced colorectal cancer and liver metastases: results from two phase I studies. J Clin Oncol 21: $3955-3964$

Motzer RJ, Hutson TE, Tomczak P, Michaelson MD, Bukowski RM, Rixe O, Oudard S, Negrier S, Szczylik C, Kim ST, Chen I, Bycott PW, Baum CM, Figlin RA (2007) Sunitinib versus interferon alfa in metastatic renal-cell carcinoma. N Engl J Med 356: 115-124

Motzer RJ, Michaelson MD, Redman BG, Hudes GR, Wilding G, Figlin RA, Ginsberg MS, Kim ST, Baum CM, DePrimo SE, Li JZ, Bello CL, Theuer CP, George DJ, Rini BI (2006) Activity of SU11248, a multitargeted inhibitor of vascular endothelial growth factor receptor and plateletderived growth factor receptor, in patients with metastatic renal cell carcinoma. J Clin Oncol 24: 16-24

Mross K, Drevs J, Muller M, Medinger M, Marme D, Hennig J, Morgan B, Lebwohl D, Masson E, Ho YY, Gunther C, Laurent D, Unger C (2005) Phase I clinical and pharmacokinetic study of PTK/ZK, a multiple VEGF receptor inhibitor, in patients with liver metastases from solid tumours. Eur J Cancer 41: 1291 - 1299

Mross KB, Gmehling D, Frost A, Baas F, Strecker R, Hennig J, Stopfer P, Stefanic M, Stehle G, de Rossi L (2005b) A clinical phase I, pharmacokinetic (PK), and pharmacodynamic study of twice daily BIBF 1120 in advanced cancer patients. J Clin Oncol (Meetings Abstracts) 23(16S): 3031 
Murga M, Fernandez-Capetillo O, Tosato G (2005) Neuropilin-1 regulates attachment in human endothelial cells independently of vascular endothelial growth factor receptor-2. Blood 105: $1992-1999$

Mutin M, Canavy I, Blann A, Bory M, Sampol J, Dignat-George F (1999) Direct evidence of endothelial injury in acute myocardial infarction and unstable angina by demonstration of circulating endothelial cells. Blood 93: $2951-2958$

Nimeiri HS, Oza AM, Morgan RJ, Friberg G, Kasza K, Faoro L, Salgia R, Stadler WM, Vokes EE, Fleming GF (2008) Efficacy and safety of bevacizumab plus erlotinib for patients with recurrent ovarian, primary peritoneal, and fallopian tube cancer: a trial of the Chicago, PMH, and California Phase II Consortia. Gynecol Oncol 110: 49-55

Norden-Zfoni A, Desai J, Manola J, Beaudry P, Force J, Maki R, Folkman J, Bello C, Baum C, DePrimo SE, Shalinsky DR, Demetri GD, Heymach JV (2007) Blood-based biomarkers of SU11248 activity and clinical outcome in patients with metastatic imatinib-resistant gastrointestinal stromal tumor. Clin Cancer Res 13: 2643-2650

Nowak DG, Woolard J, Amin EM, Konopatskaya O, Saleem MA, Churchill AJ, Ladomery MR, Harper SJ, Bates DO (2008) Expression of pro- and anti-angiogenic isoforms of VEGF is differentially regulated by splicing and growth factors. J Cell Sci 121: 3487-3495

O'Connor JP, Jayson GC, Jackson A, Ghiorghiu D, Carrington BM, Rose CJ, Mills SJ, Swindell R, Roberts C, Mitchell CL, Parker GJ (2007) Enhancing fraction predicts clinical outcome following first-line chemotherapy in patients with epithelial ovarian carcinoma. Clin Cancer Res 13: $6130-6135$

O'Donnell A, Padhani A, Hayes C, Kakkar AJ, Leach M, Trigo JM, Scurr M, Raynaud F, Phillips S, Aherne W, Hardcastle A, Workman P, Hannah A, Judson I (2005) A phase I study of the angiogenesis inhibitor SU5416 (semaxanib) in solid tumours, incorporating dynamic contrast MR pharmacodynamic end points. Br J Cancer 93: 876-883

O. Rixe JPD, Motzer RJ, Wilding G, Stadler WM, Kim S, Tarazi J, Rosbrook B, Rini B (2008) Genitourinary tumors. Ann Oncol 19: viii187 - viii207

Overmoyer B, Silverman P, Leeming R, Shenk R, Lyons J, Ziats N, Jesberger J, Dumadag L, Remick S, Chen H (2004) Phase II trial of neoadjuvant docetaxel with or without bevacizumab in patients with locally advanced breast cancer. J Clin Oncol ASCO Annual Meeting Proceedings (PostMeeting Edition) 22No 14S (15 July Supplement): 727

Padhani AR, Krohn KA, Lewis JS, Alber M (2007) Imaging oxygenation of human tumours. Eur Radiol 17: 861-872

Padhani AR, Taylor NJ, d'Arcy JA, Walker-Samuel S, Collins DJ, Knowles B, Stirling JJ, Wallace T, Koh D-M, Tang A, Lee C, Temple G, Rustin GJ, Leach MO (2006) Dynamic MRI evaluation of the triple receptor tyrosine kinase inhibitor BIBF 1120 in patients with advanced solid tumours. Proc Int Soc Mag Reson Med 14: 765

Paez-Ribes M, Allen E, Hudock J, Takeda T, Okuyama H, Vinals F, Inoue M, Bergers G, Hanahan D, Casanovas O (2009) Antiangiogenic therapy elicits malignant progression of tumors to increased local invasion and distant metastasis. Cancer Cell 15: 220-231

Pan Q, Chathery Y, Wu Y, Rathore N, Tong RK, Peale F, Bagri A, TessierLavigne M, Koch AW, Watts RJ (2007) Neuropilin-1 binds to VEGF121 and regulates endothelial cell migration and sprouting. J Biol Chem 282: 24049-24056

Peterson AC, Swiger S, Stadler WM, Medved M, Karczmar G, Gajewski TF (2004) Phase II study of the Flk-1 tyrosine kinase inhibitor SU5416 in advanced melanoma. Clin Cancer Res 10: 4048-4054

Reynolds AR, Hart IR, Watson AR, Welti JC, Silva RG, Robinson SD, Da Violante G, Gourlaouen M, Salih M, Jones MC, Jones DT, Saunders G, Kostourou V, Perron-Sierra F, Norman JC, Tucker GC, HodivalaDilke KM (2009) Stimulation of tumor growth and angiogenesis by low concentrations of RGD-mimetic integrin inhibitors. Nat Med 15: $392-400$

Riely GJ, Miller VA (2007) Vascular endothelial growth factor trap in non small cell lung cancer. Clin Cancer Res 13: s4623 - s4627

Rini BI, Michaelson MD, Rosenberg JE, Bukowski RM, Sosman JA, Stadler WM, Hutson TE, Margolin K, Harmon CS, DePrimo SE, Kim ST, Chen I, George DJ (2008a) Antitumor activity and biomarker analysis of sunitinib in patients with bevacizumab-refractory metastatic renal cell carcinoma. J Clin Oncol 26: 3743-3748

Rini BI, Schiller JH, Fruehauf JP, Cohen EE, Tarazi JC, Rosbrook B, Ricart AD, Olszanski AJ, Kim S, Spano J (2008b) Association of diastolic blood pressure $(\mathrm{dBP})>=90 \mathrm{mmHg}$ with overall survival (OS) in patients treated with axitinib (AG- 013736). J Clin Oncol (Meeting Abstracts) 26: 3543
Rosen LS, Kurzrock R, Mulay M, Van Vugt A, Purdom M, Ng C, Silverman J, Koutsoukos A, Sun YN, Bass MB, Xu RY, Polverino A, Wiezorek JS, Chang DD, Benjamin R, Herbst RS (2007) Safety, pharmacokinetics, and efficacy of AMG 706, an oral multikinase inhibitor, in patients with advanced solid tumors. J Clin Oncol 25: 2369-2376

Rowand JL, Martin G, Doyle GV, Miller MC, Pierce MS, Connelly MC, Rao C, Terstappen LW (2007) Endothelial cells in peripheral blood of healthy subjects and patients with metastatic carcinomas. Cytometry $A$ 71: $105-113$

Saltz LB, Clarke S, Diaz-Rubio E, Scheithauer W, Figer A, Wong R, Koski S, Lichinitser M, Yang TS, Rivera F, Couture F, Sirzen F, Cassidy J (2008) Bevacizumab in combination with oxaliplatin-based chemotherapy as first-line therapy in metastatic colorectal cancer: a randomized phase III study. J Clin Oncol 26: 2013-2019

Sandler A, Gray R, Perry MC, Brahmer J, Schiller JH, Dowlati A, Lilenbaum R, Johnson DH (2006) Paclitaxel-carboplatin alone or with bevacizumab for non-small-cell lung cancer. N Engl J Med 355: 2542-2550

Scartozzi M, Galizia E, Chiorrini S, Giampieri R, Berardi R, Pierantoni C, Cascinu S (2009) Arterial hypertension correlates with clinical outcome in colorectal cancer patients treated with first-line bevacizumab. Ann Oncol 20: 227-230

Schneider BP, Wang M, Radovich M, Sledge GW, Badve S, Thor A, Flockhart DA, Hancock B, Davidson N, Gralow J, Dickler M, Perez EA, Cobleigh M, Shenkier T, Edgerton S, Miller KD (2008) Association of vascular endothelial growth factor and vascular endothelial growth factor receptor-2 genetic polymorphisms with outcome in a trial of paclitaxel compared with paclitaxel plus bevacizumab in advanced breast cancer: ECOG 2100. J Clin Oncol 26: $4672-4678$

Schultheis AM, Lurje G, Rhodes KE, Zhang W, Yang D, Garcia AA, Morgan R, Gandara D, Scudder S, Oza A, Hirte H, Fleming G, Roman L, Lenz HJ (2008) Polymorphisms and clinical outcome in recurrent ovarian cancer treated with cyclophosphamide and bevacizumab. Clin Cancer Res 14: $7554-7563$

Shibuya M, Claesson-Welsh L (2006) Signal transduction by VEGF receptors in regulation of angiogenesis and lymphangiogenesis. Exp Cell Res 312: $549-560$

Shojaei F, Wu X, Malik AK, Zhong C, Baldwin ME, Schanz S, Fuh G, Gerber HP, Ferrara N (2007) Tumor refractoriness to anti-VEGF treatment is mediated by CD11b+Gr1+ myeloid cells. Nat Biotechnol 25: 911-920

Siegel AB, Cohen EI, Ocean A, Lehrer D, Goldenberg A, Knox JJ, Chen H, Clark-Garvey S, Weinberg A, Mandeli J, Christos P, Mazumdar M, Popa E, Brown Jr RS, Rafii S, Schwartz JD (2008) Phase II trial evaluating the clinical and biologic effects of bevacizumab in unresectable hepatocellular carcinoma. J Clin Oncol 26: 2992-2998

Sohn HJ, Yang YJ, Ryu JS, Oh SJ, Im KC, Moon DH, Lee DH, Suh C, Lee JS, Kim SW (2008) [18F]fluorothymidine positron emission tomography before and 7 days after gefitinib treatment predicts response in patients with advanced adenocarcinoma of the lung. Clin Cancer Res 14: $7423-7429$

Soker S, Takashima S, Miao HQ, Neufeld G, Klagsbrun M (1998) Neuropilin-1 is expressed by endothelial and tumor cells as an isoform-specific receptor for vascular endothelial growth factor. Cell 92: 735-745

Stadler WM, Cao D, Vogelzang NJ, Ryan CW, Hoving K, Wright R, Karrison T, Vokes EE (2004) A randomized phase II trial of the antiangiogenic agent SU5416 in hormone-refractory prostate cancer. Clin Cancer Res 10: $3365-3370$

Stopeck A, Sheldon M, Vahedian M, Cropp G, Gosalia R, Hannah A (2002) Results of a phase I dose-escalating study of the antiangiogenic agent, SU5416, in patients with advanced malignancies. Clin Cancer Res 8: $2798-2805$

Thomas AL, Morgan B, Horsfield MA, Higginson A, Kay A, Lee L, Masson E, Puccio-Pick M, Laurent D, Steward WP (2005) Phase I study of the safety, tolerability, pharmacokinetics, and pharmacodynamics of PTK787/ZK 222584 administered twice daily in patients with advanced cancer. J Clin Oncol 23: $4162-4171$

Ton NC, Parker GJ, Jackson A, Mullamitha S, Buonaccorsi GA, Roberts C, Watson Y, Davies K, Cheung S, Hope L, Power F, Lawrance J, Valle J, Saunders M, Felix R, Soranson JA, Rolfe L, Zinkewich-Peotti K, Jayson GC (2007) Phase I evaluation of CDP791, a PEGylated di-Fab' conjugate that binds vascular endothelial growth factor receptor 2. Clin Cancer Res 13: $7113-7118$

Varey AH, Rennel ES, Qiu Y, Bevan HS, Perrin RM, Raffy S, Dixon AR, Paraskeva C, Zaccheo O, Hassan AB, Harper SJ, Bates DO (2008) VEGF $165 \mathrm{~b}$, an antiangiogenic VEGF-A isoform, binds and inhibits bevacizumab treatment in experimental colorectal carcinoma: balance 
of pro- and antiangiogenic VEGF-A isoforms has implications for therapy. Br J Cancer 98: $1366-1379$

Varker KA, Biber JE, Kefauver C, Jensen R, Lehman A, Young D, Wu H, Lesinski GB, Kendra K, Chen HX, Walker MJ, Carson III WE (2007) A randomized phase 2 trial of bevacizumab with or without daily lowdose interferon alfa-2b in metastatic malignant melanoma. Ann Surg Oncol 14: $2367-2376$

Wedam SB, Low JA, Yang SX, Chow CK, Choyke P, Danforth D, Hewitt SM, Berman A, Steinberg SM, Liewehr DJ, Plehn J, Doshi A, Thomasson D, McCarthy N, Koeppen H, Sherman M, Zujewski J, Camphausen K, Chen H, Swain SM (2006) Antiangiogenic and antitumor effects of bevacizumab in patients with inflammatory and locally advanced breast cancer. J Clin Oncol 24: 769-777

Willett CG, Boucher Y, di Tomaso E, Duda DG, Munn LL, Tong RT, Chung DC, Sahani DV, Kalva SP, Kozin SV, Mino M, Cohen KS, Scadden DT, Hartford AC, Fischman AJ, Clark JW, Ryan DP, Zhu AX, Blaszkowsky LS, Chen HX, Shellito PC, Lauwers GY, Jain RK (2004) Direct evidence that the VEGF-specific antibody bevacizumab has antivascular effects in human rectal cancer. Nat Med 10: 145-147

Willett CG, Boucher Y, Duda DG, di Tomaso E, Munn LL, Tong RT, Kozin SV, Petit L, Jain RK, Chung DC, Sahani DV, Kalva SP, Cohen KS, Scadden DT, Fischman AJ, Clark JW, Ryan DP, Zhu AX, Blaszkowsky LS, Shellito PC, Mino-Kenudson M, Lauwers GY (2005) Surrogate markers for antiangiogenic therapy and dose-limiting toxicities for bevacizumab with radiation and chemotherapy: continued experience of a phase I trial in rectal cancer patients. J Clin Oncol 23: 8136-8139

Xiong HQ, Herbst R, Faria SC, Scholz C, Davis D, Jackson EF, Madden T, McConkey D, Hicks M, Hess K, Charnsangavej CA, Abbruzzese JL (2004) A phase I surrogate endpoint study of SU6668 in patients with solid tumors. Invest New Drugs 22: 459-466

Yamada K, Hirata T, Fujiwara Y, Nokihara H, Yamamoto N, Yamada Y, Koizumi K, Nishio K, Koyama N, Tamura T (2008) Phase I dose escalation study and biomarker analysis of E7080 in patients with advanced solid tumors. J Clin Oncol 26: 2008 (20 May suppl; abstract 3527)

Yang JC, Haworth L, Sherry RM, Hwu P, Schwartzentruber DJ, Topalian SL, Steinberg SM, Chen HX, Rosenberg SA (2003) A randomized trial of bevacizumab, an anti-vascular endothelial growth factor antibody, for metastatic renal cancer. $N$ Engl J Med 349: 427-434

Yang SX, Steinberg SM, Nguyen D, Wu TD, Modrusan Z, Swain SM (2008) Gene expression profile and angiogenic marker correlates with response to neoadjuvant bevacizumab followed by bevacizumab plus chemotherapy in breast cancer. Clin Cancer Res 14: 5893-5899

Yao JC, Phan A, Hoff PM, Chen HX, Charnsangavej C, Yeung SC, Hess K, Ng C, Abbruzzese JL, Ajani JA (2008) Targeting vascular endothelial growth factor in advanced carcinoid tumor: a random assignment phase II study of depot octreotide with bevacizumab and pegylated interferon alpha-2b. J Clin Oncol 26: 1316-1323 